\title{
BIOLOGICAL AND SOCIAL ECONOMIC FACTORS AFFECTING TREATMENT COMPLAINT AND CURE AMONG TUBERCULOSIS PATIENTS IN YOGYAKARTA
}

\author{
Tri Godha Fitriani'), Setyo Sri Rahardjo2), Hanung Prasetya3) \\ ${ }^{1)}$ Masters Program in Public Health, Universitas Sebelas Maret \\ 2)Faculty of Medicine, Universitas Sebelas Maret \\ 3)School of Health Polytechnics Surakarta
}

\begin{abstract}
Background: TB can be cured in almost all cases by taking the medications as prescribed by the doctor for the full course of treatment (at least six months). All patients receiving $\mathrm{TB}$ treatment should be monitored during their treatment to assess their response to the drug treatment. Regular monitoring also helps to ensure that patients complete their treatment. It can also help to identify and manage adverse drug reactions. This study aimed to examine biological and social economic factors affecting treatment complaint and cure among tuberculosis patients.

Subjects and Method: A cross-sectional study was carried out in Bantul, Yogyakarta, from April to May 2019. A sample of 225 TB patients was selected by random sampling. The dependent variable was treatment cure. The independent variables were age, gender, education, income, nutritional status, health behavior, complication, family support, drug taking supervisor, drug taking adherence, environmental, and smoking. The data were collected by questionnaire and analyzed by a multiple logistic regression.

Results: TB treatment cure decreased with aged $\geq 65$ years old $(b=-0.82 ; 95 \% \mathrm{CI}=0.16$ to $2.13 ; \mathrm{p}=0.900)$, female $(\mathrm{b}=-0.13 ; 95 \% \mathrm{CI}=0.42$ to $2.14 ; \mathrm{p}=0.411)$, complication $(\mathrm{b}=$ $-2.34 ; 95 \% \mathrm{CI}=0.07$ to $0.79 ; \mathrm{p}=0.019)$, smoking $(\mathrm{b}=-2.74 ; 95 \% \mathrm{CI}=0.07$ to $0.65 ; \mathrm{p}=$ o.o06), unhealthy behavior $(\mathrm{b}=-3.42 ; 95 \% \mathrm{CI}=0.006$ to $0.25 ; \mathrm{p}=0.001)$, and weak family support $(b=-2.19 ; 95 \% \mathrm{CI}=0.02$ to $0.80 ; \mathrm{p}=0.029)$. TB treatment cure increased with drug taking supervisor $(b=3.00 ; 95 \% \mathrm{CI}=3.53$ to $411.86 ; \mathrm{p}=0.003$ ), healthy environment $(b=1.91 ; 95 \% \mathrm{CI}=0.90$ to $3661.39 ; \mathrm{p}=0.056)$, drug taking adherence $(b=3.26 ; 95 \% \mathrm{CI}=4.38$ to $372.66 ; \mathrm{p}=0.001)$, family income $(\mathrm{b}=1.17 ; 95 \%$ $\mathrm{CI}=0.65$ to $5.50 ; \mathrm{p}=0.244)$, good nutritional status $(\mathrm{b}=2.04 ; 95 \% \mathrm{CI}=1.02$ to $4.43 ; \mathrm{p}=$ 0.042).

Conclusion: TB treatment cure decreases with aged $\geq 65$ years old, female, complication, smoking, unhealthy behavior, and weak family support. TB treatment cure increases with drug taking supervisor, healthy environment, drug taking adherence, family income, and good nutritional status.
\end{abstract}

Keywords: tuberculosis, treatment complaint and cure, unhealthy behavior

\section{Correspondence:}

Tri Godha Fitriani. Masters Program in Public Health. Universitas Sebelas Maret. Jl. Ir. Sutami 36A, Surakarta 57126, Central Java. Email: trigodha@gmail.com. Mobile: +6287738200610 . 